\title{
Increasing Research Productivity in Small Universities: A Case Study
}

\author{
WAYNE B. INGALLS*
}

\begin{abstract}
Researchers at small Canadian universities encounter a set of problems which hamper their productivity. The administration of one such institution embarked upon a programme to increase the research output of its faculty which met with spectacular success. This success occurred because the administration signaled its support for research by devoting resources to it and because faculty learned that they could compete for grants successfully.
\end{abstract}

\section{RÉSUMÉ}

Les chercheurs des petites universités canadiennes rencontrent un ensemble de problèmes qui gênent leur productivité. L'administration d'une petite université a lancé un programme pour augmenter la recherche et il a eu un succès spectaculaire. Ce résultat a été possible parce que l'administration a signalé son appui en consacrant des ressources à la recherche et les membres de la faculté ont appris qu'ils pouvaient concourir et réussir à obtenir des subventions.

\section{INTRODUCTION}

Two important studies published in the middle seventies described in detail the problems of those undertaking research at small Canadian universities (Overgaard 1975 and Canada Council 1977). The difficulties and obstacles that such researchers encounter might well be summarized as follows:

1. lack of a research tradition and orientation;

2. heavy teaching loads in terms of both contact hours and student numbers;

3. few graduate programmes to provide assistants or stimulus;

4. little internal funding available for research;

5. inadequate secretarial assistance;

* Director of Research and Special Projects, Mount Saint Vincent University 
6. inadequate research facilities, including scientific equipment, library and archival resources, and large data banks

7. limited contact with others in field because of departmental size and location in isolated communities.

Such difficulties have traditionally led to a lower level of research productivity than what is normally found at larger Canadian universities.

In a more recent publication, J. Philippe Rushton and Sari Meltzer examined the obverse side of this phenomenon. Using a number of indicators, including number of publications cited, revenue, student numbers, faculty size, year of foundation, number of volumes in the library, and number of current periodicals, they demonstrated that the universities with the greatest scholarly impact are those which are both wealthiest and largest (Rushton and Meltzer 1979, 1980). By and large, the smaller universities, which the Canada Council's Consultative Group defined as having a student population under 3500 , were not even included in the Rushton and Meltzer study.

A parallel situation appears to exist in the U.S., where 100 leading research universities perform approximately 85 percent of the sponsored research carried out by institutions of higher learning (McCoy et al 1982). Indeed, the authors of another U.S.-based study suggest that the position of weaker departments and institutions will deteriorate over the coming years, thereby reducing their ability to compete for research funding (Smith and Karlesky 1978).

As the recent AUCC-sponsored Leslie Report and the Science Council have noted, every indication points to a difficult time ahead for Canadian universities large and small (Leslie 1980, Science Council 1979). In this context and with the problems that already beset researchers at smaller institutions, administrators, who are eager to increase the level of research activity in smaller universities, can hardly be blamed for being disheartened.

The task before them, however, may be less formidable than they believe. One small Canadian institution has been able to achieve considerable success in fostering research activity and generating research funding. The purpose of this paper is to describe its achievement and to offer a brief analysis of its success.

\section{CASE STUDY}

Mount Saint Vincent is small by Canadian university standards. The full-time enrolment for the 1981.82 academic year was 1465 , while 1563 part-time students attended. There were 97 full-time and 67 part-time faculty. In 1974, the administration set out upon a programme to increase the research productivity of its faculty. This programme consisted of the following measures:

1. The creation of an office of research administration and the appointment of a Director of Research and Publications.

2. The creation of a Presidential Committee to make recommendations on research policy and the allocation of internally funded research grants. 
61 Increasing Research Productivity in Small Universities: A Case Study

Table 1

Growth in Student Numbers

$1974-82$

\begin{tabular}{|c|c|c|c|}
\hline Year & $\begin{array}{l}\text { Full-time } \\
\text { Enrolment }\end{array}$ & $\begin{array}{l}\text { Part-time } \\
\text { Enrolment }\end{array}$ & $\begin{array}{c}\text { Total } \\
\text { Enrolment }\end{array}$ \\
\hline $1974-75$ & 1179 & 502 & 1681 \\
\hline $1975-76$ & 1335 & 729 & 2064 \\
\hline $1976-77$ & 1431 & 794 & 2225 \\
\hline $1977-78$ & 1523 & 876 & 2399 \\
\hline $1978-79$ & 1466 & 823 & 2289 \\
\hline $1979-80$ & 1581 & 909 & 2490 \\
\hline $1980-81$ & 1466 & 1097 & 2563 \\
\hline $1981-82$ & 1465 & 1563 & 3028 \\
\hline $\begin{array}{l}\text { Percentage } \\
\text { growth rate }\end{array}$ & 24.38 & 211.48 & 80.18 \\
\hline
\end{tabular}

Table 2

Growth in Faculty

1974-82

Year

$1974-75$

$1975-76$

$1976-77$

$1977-78$

$1978-79$

$1979-80$

$1980-81$

$1981-82$

Overall

growth

rate

$\begin{array}{cccc}\text { Full-time } & & \text { Part-time } & \text { Total } \\ 77 & 35 & 112 \\ 80 & 45 & 125 \\ 85 & 60 & 145 \\ 90 & 70 & 160 \\ 100 & 55 & 155 \\ 88 & 76 & 164 \\ 97 & 77 & 174 \\ 99 & 67 & 166 \\ 28.68 & 91.48 & 48.28\end{array}$

3. The implementation of hiring policies intended to recruit and retain faculty with either a proven record of research productivity or the potential to develop research programmes.

4. The allocation of funds from the university's operating budget to provide seed money to support the research of promising scholars.

5. The establishment of a faculty research seminar.

6. The allocation on a priority basis of faculty travel funds to those attending conferences to present their research findings.

7. The creation of a programme of sabbatical leave grants. 
Although none of these measures is very remarkable, they did lead to a spectacular increase in research activity as the following tables illustrate. The first two tables show the growth in student and faculty numbers respectively, while the third shows the growth in research funding.

As the final table indicates, the research funds generated in 1981-82 represent roughly a 4000 percent increase over the 1973-74 total! Apart from the percentage growth, the total figures are not impressive when compared to the research revenue of Canada's larger universities, but they become more so if the following facts are taken into consideration.

Mount Saint Vincent has one of the smallest complements of natural scientists of any Canadian university, and while they are every bit as productive as scholars at other institutions, they cannot be expected to generate the levels of NSERC funding obtained by their colleagues at other universities. Accordingly, the Natural Sciences and Engineering Research Council's contribution to the total research budget for $1981-82$ is less than 20 percent. Compare the situation at Dalhousie University. In $1980-81$, Dalhousie received a total of $\$ 6,656,730$ in research grants from federal agencies (NRC 1981). Of this amount, the Natural Sciences accounted for 57.6 percent, Health Sciences for 38.5 percent, and Business, Humanities and the Social Sciences for the remaining 3.9 percent. With no medical school and only a handful of natural scientists eligible for NSERC grants, the success of the faculty at Mount Saint Vincent looks impressive indeed.

\section{REASONS FOR SUCCESS}

By now, the point has been made that, while small, Mount Saint Vincent has been successful in its efforts to increase the research productivity of its faculty. The question which now should be addressed is why was Mount Saint Vincent successful.

It is clear that the measures taken are hardly different from those found in other universities. The reason for the success appears rather to be found in the attitudes of two groups, the senior administration and the faculty. The administration for its part made a serious commitment to support research. To this end, they were willing to appoint the then academic dean's only assistant as director of research, adding research to his other duties, and they were willing to provide funding. It should be noted, however, that these funds have never been very generous. In the first year, the research committee was given only $\$ 1000$. But that sum, however modest, did signal a major shift in the administration's attitude toward research. Now, with the addition of the general research grants from the councils, the committee has roughly $\$ 60,000$ at its disposal.

To achieve the success, a change of attitude among faculty was also required. At first, researchers doubted that they could obtain research funding from external sources. Since Mount Saint Vincent is Canada's only university primarily oriented to the educational needs of women, it has attracted a larger than average number of women faculty. These scholars were well aware that women were 


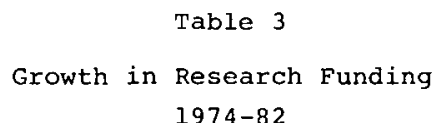

$1974-82$

\begin{tabular}{|c|c|c|c|}
\hline Year & Agency & Amount & Total \\
\hline $1973-74$ & $\begin{array}{l}\text { NRC } \\
\text { Canada Council }\end{array}$ & $\begin{array}{l}6.000 \\
7,057\end{array}$ & $\$ 13,057$ \\
\hline $1974-75$ & $\begin{array}{l}\text { NRC } \\
\text { Canada Council }\end{array}$ & $\begin{array}{r}22,000 \\
1,377\end{array}$ & 23,377 \\
\hline $1975-76$ & $\begin{array}{l}\text { NRC } \\
\text { Canada Council }\end{array}$ & $\begin{array}{r}28,500 \\
8,841\end{array}$ & 37,341 \\
\hline $1976-77$ & $\begin{array}{l}\text { NRC } \\
\text { Canada Council }\end{array}$ & $\begin{array}{l}31,634 \\
30,747\end{array}$ & 62,381 \\
\hline $1977-78$ & $\begin{array}{l}\text { NRC } \\
\text { Canada Council } 1\end{array}$ & $\begin{array}{l}28,512 \\
32,424\end{array}$ & 60,936 \\
\hline $1978-79$ & $\begin{array}{l}\text { NSERC } \\
\text { SSHRC } \\
\text { Other }\end{array}$ & $\begin{array}{l}36,817 \\
60,427 \\
40,707\end{array}$ & 137,951 \\
\hline $1979-80$ & $\begin{array}{l}\text { NSERC } \\
\text { SSHRC } \\
\text { Other }\end{array}$ & $\begin{array}{r}46,016 \\
113,480 \\
61,183\end{array}$ & 220,679 \\
\hline $1980-81$ & $\begin{array}{l}\text { NSERC } \\
\text { SSHRC } \\
\text { Other }\end{array}$ & $\begin{array}{r}68,279 \\
138,044 \\
253,245\end{array}$ & 459,568 \\
\hline $1981-82$ & $\begin{array}{l}\text { NSERC } \\
\text { SSHRC } \\
\text { Other }\end{array}$ & $\begin{array}{r}149,771 \\
344,929 \\
63,935\end{array}$ & 558,635 \\
\hline
\end{tabular}

under-represented both in the research councils' programmes and in their adjudication committees. Again, as Maritimers, they felt at a disadvantage applying to councils located in central Canada. Finally, as scholars from a small university, they felt their chances of success were not good. After a few successes, however, the attitude appears to have changed to the point where it is safe to say that there is little research at Mount Saint Vincent worthy of the name that is not receiving support.

This programme, of course, places heavy demands on faculty, who receive no release time to do their research and carry the heavier-than-normal teaching loads typical of smaller universities. But they appear to have accepted these burdens because of the importance they place on research in their professional lives.

The success of Mount Saint Vincent demonstrates that despite a bleak economic environment and a set of problems peculiar to researchers at smaller institutions, it is possible for a small university to increase the research productivity of its faculty. Increasingly, universities are being asked to justify the enormous contribution of the Canadian public to their maintenance. Research, of course, being that which makes a post-secondary institution a university, can provide 
examples of the value of the universities to the communities in which they are located. As the case of Mount Saint Vincent illustrates, even small universities can play a part in the Canadian research mosaic.

\section{REFERENCES}

Canada Council. Needs of Scholars at Small Universities. Ottawa: Canada Council, 1977.

Leslie, P. Canadian Universities: 1980 and Beyond (AUCC Policy Studies No. 3). Ottawa: Association of Universities and Colleges of Canada, 1980.

McCoy, M., Krakower, J., and Makowski, D. Financing at the Leading 100 Research Universities: A Study of Financial Dependency, Concentration, and Related Institutional Characteristics. Research in Higher Education, 1982, 16, 323-352.

National Research Council. Directory of Federally Supported Research in Universities, Volume 1, 1980-81. Ottawa: National Research Council, 1981.

Overgaard, H. Problems of Social Science Research at Smaller Canadian Universities. Ottawa: Social Science Research Council of Canada, 1975.

Rushton, J.P. and Meltzer, S. Research Productivity, University Revenue, and Scholarly Impact of 31 Canadian Universities. Canadian Journal of Higher Education, $1979,9,74-81$.

Rushton, J.P. and Meltzer, S. Research Productivity, University Revenue, and Scholarly Impact of 31 Canadian Universities: An Update. Canadian Journal of Higher Education, 1980, 10, 121.

Science Council of Canada. University Research in Jeopardy: The Threat of Declining Enrolment (Report 31). Ottawa: Science Council of Canada, 1979.

Smith, B.L.R., and Karlesky, J.J. The State of Academic Science (Volume II - Background Papers). New Rochelle, 1978. 